\title{
'ENAK' BALL AS A ENVIRONMENTALLY FRIENDLY MULTISENSORIAL GAME TOOLS
}

\author{
Nurul Fadhilah, Yuyun Rahmawati, Wahyuni Novitasari, Faisal Khamdani \\ Universitas Muhammadiyah Magelang \\ nurul.cuitzt18@gmail.com
}

Article History

accepted 09/07/2018

approved 01/08/2018

published 17/09/2018

\section{Keywords}

media bola ENAK,

Multisensori, Ramah

Lingkungan

\begin{abstract}
Media pembelajaran anak usia dini sangat pentinguntuk Optimalisasi Tumbuh Kembang Anak, olehkarena itu berbagai media pembelajaran sangat diperlukan oleh para pendidik, praktisi PAUD, serta pemerhati Pendidikan Anak usia Dini lainnya ketika melaksanakan program pendidikan. Salah satu media yang dipergunakan untuk program pendidikan pada anak usia dini bersifat multisensori dan ramah lingkungan yaitu bola ENAK (edukatif, nyaman, atraktif, dan kreatif). Berdasarkan survei serta observasi tidak langsung terhadap analisis kebutuhan yang dilakukan penulis terhadap para pendidik dan pemerhati PAUD diperoleh informasi, bahwa: 1) Para Pendidik dan permerhati PAUD sepakat jika dilakukan upaya pengadaan media pembelajaran yang lebih atraktif, multifungsi, multisensori dan ramah lingkungan sehingga dapat digunakan sebagai alternatif yang konstruktif dan variatif sebagai media pembelajaran yang menyenangkan; 2) $100 \%$ pendidik dan pemerhati PAUD menyetujui bahwa pengembangan media bola dilakukan lebih beragam fungsi, tekstur dan bahan yang digunakan. Penulis melakukan berbagai upaya sebagai berikut : 1) Pengadaan Bola ENAK yang dimodifikasi meliputi 9 varian terdiri dari PhoneticBall, Numeric Ball, Shape Ball, Expression Ball, Musical Ball, FF Ball, Texture Ball, Calour Ball, Reliqius Ball; 2) Menganalisis kebutuhan para pendidik dan pemerhati PAUD umum; 3) Menyusun rancangan produk awal; 4) Mengembangkan media Bola ENAK serta Uji Ahli; 5) Melakukan revisi produk; 6) Menghasilkan finising Bola ENAK sebagai model akhir; 7) Melakukan marketing keberbagai sasaran. Media Bola ENAK sebagai alat permainan multisensori yang ramah lingkungan dapat dijadikan media pembelajaran pada anak usia dini lebih inovatif.
\end{abstract}

Social, Humanities, and Education Studies (SHEs): Conference Series https://jurnal.uns.ac.id/shes
p-ISSN 2620-9284 e-ISSN 2620-9292 


\section{PENDAHULUAN}

Berbagai penelitian menyatakan adanya hubungan yang erat dan signifikan antara media pembelajaran dan hasil belajar. Di awal kehidupan otak anak sangat sensitif dan mudah dipengaruhi oleh pengalaman baik yang positif (pengasuhan yang sehat) dan pengalaman negatif (kekerasan dan pengabaian). Media pembelajaran sesuai dengan karakteristik anak, memiliki daya ketertarikan tinggi, sangat baik terhadap memaksimalkan tumbuh kembang anak dalam berpikir hal, merasa, berelasi dan berfungsi baik di masa sekarang maupun di masa mendatang.

Hingga saat ini terdapat banyak hasil penelitian dan kajian ilmiah yang menunjukkan hubungan yang erat antara media pembelajaran kreatif inovatif dan prestasi belajar. Anak yang menerima informasi, kegiatan, serta aktifitas dalam situasi tenang dan menyenangkan, menyerap pola perilaku kondusif sangat baik untuk perkembangan otot dan sistem saraf anak. Media Pembelajaran yang aktraktif dapat membantu memaksimalkan kemapuan berfikir, fokus, menimbang, kendali perilaku dan menenangkan diri. Efek positif lain yang diakibatkan Media pembelajaran yang multisensori adalah berkurangnya fungsi saraf bertahun kemudian, bertambahnya kecakapan verbal dan performa, serta IQ,optimalnya perkembangan mental (personal, sosial, dan motor).

Menyadari betapa pentingnya fungsi media pembelajaran multisensori yang ramah lingkungan. Salah satu upaya yang dapat dilakukan pada anak-anak yaitu melalui alat permainan Bola ENAK.

Penting untuk diperhatikan bahwa dalam kegiatan bermain dan pembelajaran pada anak usia dini diperlukan media yang representatif. Media yang ideal untuk kegiatan bermain dan pembelajaran bukan hanya sekedar mengenal karakter bentuk atau material saja, tetapi fungsi atau daya guna dari media inipun haruslah diperhatikan. Fungsi sebuah media bermain dan pembelajaranakan mengikat hati dan pikiran anak, sehingga akan memantapkan makna dan daya serapnya terhadap benda tersebut. Anak lebih merasakan (sensing)sensasi visual dari setiap media yang dilihatnya, baik bentuk, bahan, maupun warnanya. Respon dan sensasi yang muncul dari anak terlihat berbeda, tidak hanya sekedar melihat atau mengamati bentuk dan warna saja, tetapi juga meraba, mendudukinya, membolak- balik, menggeser dan seterusnya. Tampak bahwa aktivitas ini menjadi lebih beragam, atraktif, dan kreatif, serta penuh tantangan.

Selanjutnya, tidak terlalu sulit untuk membuat media bermain dan pembelajaran yang murah dan mudah di sekitar kita. Banyak alternatif yang dapat digunakan asal kreatif menciptakan berbagai media bermain dan pembelajaranyang multifungsi, inovatif, dan kreatif. Kreativitas tetap perlu dibangun dan diwujudkan pada ranah sebab pendidikan, perlindungan, dan pengasuhan pada anak haruslah tetap diselenggarakan serta sebagai upaya mengurangi resiko bentuk-bentuk perilaku menyimpang pada anak.

\section{METODE}

Sejalan dengan tujuan akhir dari keseluruhan jalannya kegiatan yaitu penyusunan media kegiatan bermain dan pembelajaran untuk anak usia dini lalu melakukan fungsi marketting. Dipergunakannya metode ini karena penulis melakukan Program Kreativitas Mahasiswa- Kewirausahaan (PKM-K) sebagai respon kreatif positif terhadap program DIKTI.

Tujuan yang ingin dicapai dari pelaksanaan kegiatan adalah untuk menghasilkan satu media kegiatan bermain dan pembelajaran yang multisensori berbasis ramah lingkungan yang diberi nama Bola ENAK (Edukatif, Nyaman, Atraktif dan Kreatif). Untuk mewujudkan hal tersebut maka kegiatan PKM-K ini dilaksanakan dalam beberapa langkah meliputi: 
a) Mengidentifikasi keberadaan media bermain dan pembelajaran pada program pendidikan anak usia dini yang dipergunakan, serta

b) Membuat media bermain dan pembelajaran Bola ENAK multisensori berbasis ramah lingkungan.

c) Melakukan kegiatan marketing meliputi

(1) Pemasangan iklan sosial media (Koran, Facebook, Instagram),

(2) Media promosi melalui brosur, poster, dan banner yang dipasang di beberapa tempat strategis, diantaranyaberbagai lembaga-lembaga pendidikan.

(3) Dijual berbagai lembaga-lembaga pendidikan melalui lembaga-lembaga profesi dan Dinas Pendidikan Bidang PNF se-kota, kabupaten Magelang dan sekitarnya serta para pemerhati PAUD.

\section{PEMBAHASAN}

Hasil yang telah dicapai untuk Kegiatan PKM-K Bola ENAK Multisensori berbasis Ramah Lingkungan.

Berdasarkan hasil survei dan observasi langsung dengan tahapan kegiatan didapat temuan bahwa media kegiatan bermain dan pembelajaran dalam bentuk Bola yang selama ini masih monoton, konvensional, dan parsial.

Dengan kata lain tidak terdapat dan belum dijumpai Bola sebagai media kegiatan bermain dan pembelajaran yang memenuhi kriteria PKM-K ini. Sebagai contoh: media bola yang dijumpai belum memenuhi kriteria Multisensori dan belum Ramah Lingkungan. Bola- bola tersebut masih sangat sederhana bentuk dan fungsinya. Itu berarti media kegiatan bermain dan pembelajaran Bola ENAK (Edukatif, Nyaman, Atratif, dan Kreatif) Multisensori berbasis Ramah lingkungan yang benar-benar merupakan media inovasi baru karena belum ada model sejenis dipasaran.

Penulis mengintegrasikan 6 aspek pengembangan yang terdapat pada kurikulum pendidikan anak usia dini dengan 9 indikator. Hal ini peneliti peroleh melalui kegiatan survei dan pengamatan langsung ke lapangan. Dari berbagai hal tersebut penulis berinisiasi mengintegrasikan Multiple Intelligence dalam penggunaan media kegiatan bermain dan pembelajaran melalui Bola ENAK secara empirik; juga melakukan modifikasi prosedur penggunaan media Bola ENAK.

Mengintegrasikan 6 aspek pengembangan pada media Bola ENAK

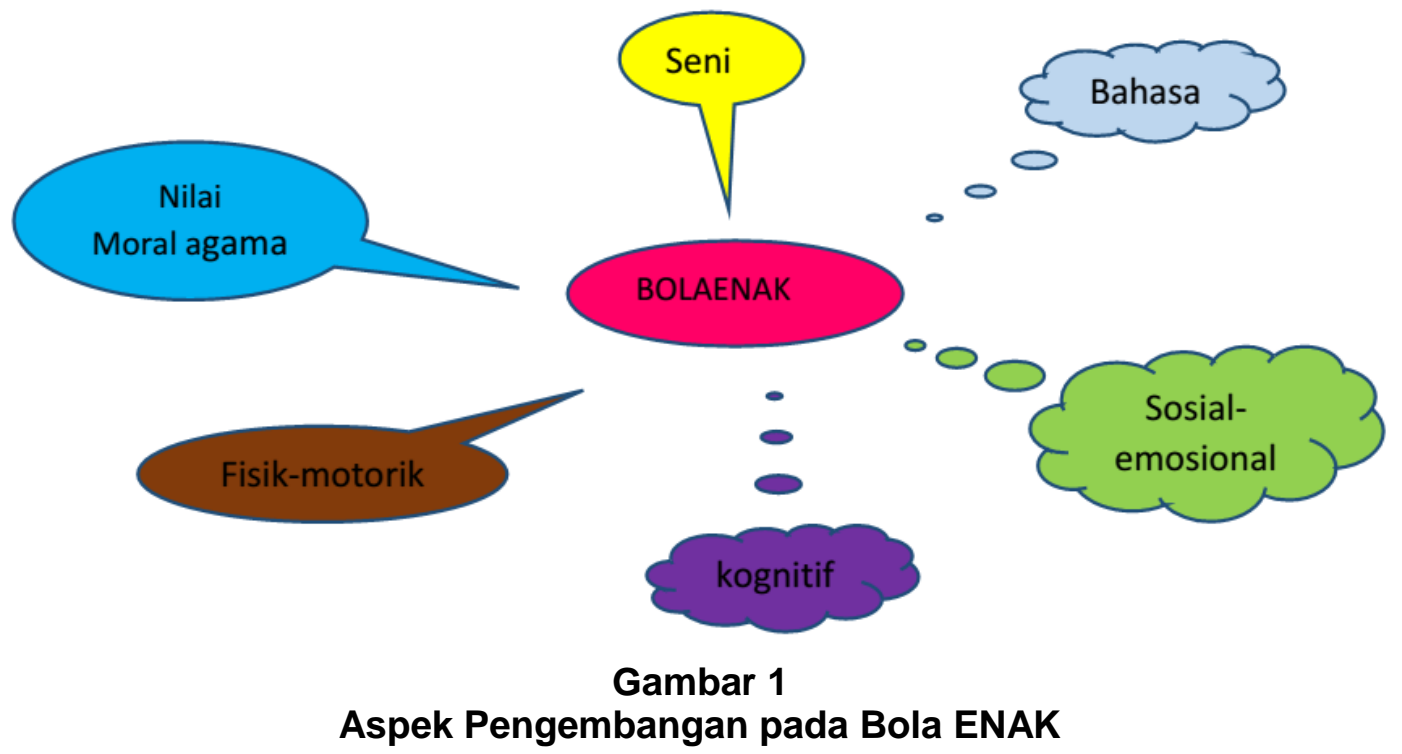


b. Mengintegrasikan indikator-indikator Multiple Intelligence

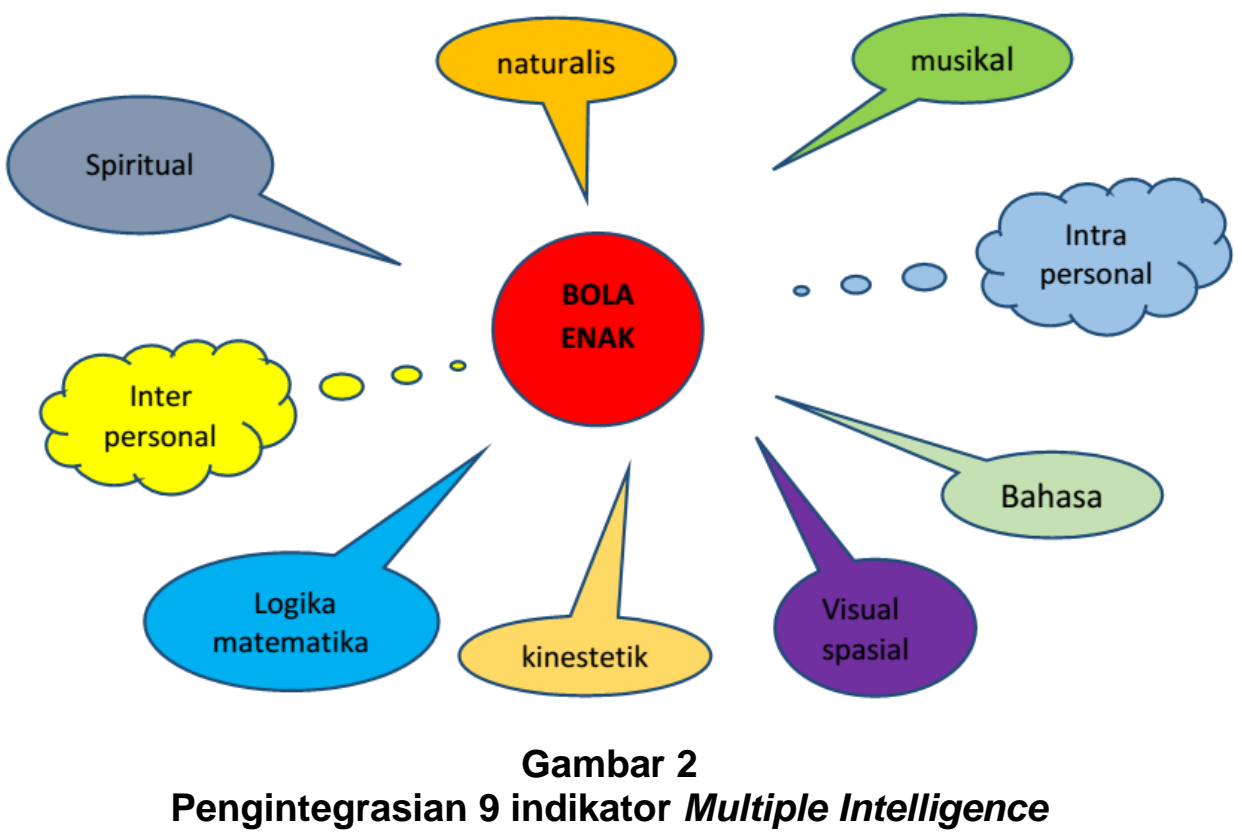

Berdasar Gambar 1 pengintegrasian 6 aspek perkembangan, media Bola ENAK dalam penggunaannya pada program kegiatan bermian dan pembelajaran anak usia memasukkan/ memadukan ke enam aspek perkembangan anak yang meliputi: perkembangan nilai agama dan moral, perkembangan bahasa, aspek perkembangan fisik motorik, kognitif, perkembangan sosial- emosional, dan aspek perkembangan seni.

Gambar 2 mengilustrasikan bahwa pengintegrasian 9 kecerdasan Multiple Intelligence, media Bola ENAK dalam penggunaannya ke sembilan indikator Multiple Intelligence mencakup: kecerdasan sosial-emosional, kecerdasan naturalis, kecerdasan musikal, intrapersonal, kecerdasan bahasa, visual-spasial, kecerdasan kinestetik, logika matematika, dan kecerdasan interpersonal. Modifikasi prosedur kegiatan bermain berbasis Multiple Intelligence ini juga diimplementasikan dalam setiap saat kegiatan yang dijabarkan dalam kegiatan pembuka, inti, dan kegiatan penutup. Pada setiap kegiatan penggunaan media Bola ENAK tidak sekedar mengikuti prosedur seperti biasanya, namun dilakukan kegiatan- kegiatan lain pada kegiatan inti permainan yang dapat dilakukan sebelum, pada saat inti kegiatan dan setelah kegiatan bermain dan pembelajaran dilakukan. Modifikasi prosedur tampak pada Gambar 3. Berikut:

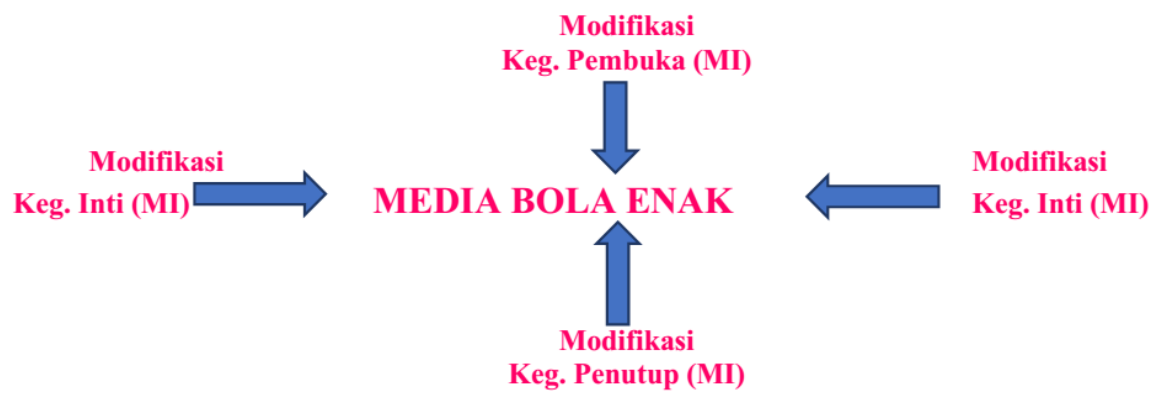


Hasil Akhir Media Bola ENAK Multisensori berbasis Ramah Lingkungan Output/ Luaran akhir dari PKM-K ini berupa Bola ENAK dengan 9 varian yang terdiri dari

\begin{tabular}{|l|l|}
\hline \multicolumn{1}{|c|}{ Nama Bola } & Macam Varian \\
\hline \multirow{5}{*}{ Media Bola ENAK } & Phonetic Ball \\
\cline { 2 - 2 } & Numeric Ball \\
\cline { 2 - 2 } & Shape Ball \\
\cline { 2 - 2 } & Ekspression Ball \\
\cline { 2 - 2 } & FF Ball \\
\cline { 2 - 2 } & Texture Ball \\
\cline { 2 - 2 } & Calour Ball \\
\cline { 2 - 2 } & Reliqius Ball \\
\hline
\end{tabular}

Berdasarkan temuan yang dilakukan oleh Madyawati (2016) ini media-media kegiatan bermain dan pembelajaran anak usia dini di banyak tempat di berbagai daerah masih parsial, belum multisensori berbasis lingkungan serta kurang dapat mengasaha Multiple Intelligence. Hal ini sejalan dengan kajian ilmiahRokhmawati (2013), bahwa media-media bola yang telah ada belum memberikan banyak pilihan kegiatan kepada anak. Padahal anak- anak pada usia dini sangat membutuhkan kondisi yang fununtuk dapat bereksplorasi, intensitas, densitas ke kondisi kegiatan bermain yang aktraktif, kreatif, dan menyenangkan. Dengan pemenuhan berbagai media 'Bola' yang sekaligus multisensori berbasis ramah lingkungan yang juga mampu mengasah Multiple Intelligence anak mampu mengoptimalkan tumbuh kembangnya. Dalam kegiatan bermain dan pembelajaran pada anak usia dini diperlukan media media yang variatif 'Bola' yang representatif, multisensori berbasis lingkungan yang dikembangkan dengan memperhatikan kebutuhan, tahapan perkembangan, dan karakteristik anak yang disebut dengan 'Bola ENAK' (Bola Edukatif, Nyaman, Atraktif, dan Kreatif).

\section{KESIMPULAN}

Berdasarkan hasil kajian mendalam dapat disimpulkan bahwa belum terdapat media kegaiatan bermain dan pembelajaran 'Bola' yang benar benar multisensori berbasis ramah lingkungan dan menerapkan Multiple Intelligence.Ini berarti bahwa media kegiatan bermain dan pembelajaran anak : Bola ENAK yang dikembangkan ini tergolong inovasi baru.

Penulis memutuskan untuk mengembangkan media kegiatan bermain dan pembelajaran anak'Bola ENAK' mengacu pada landasan konseptual tentang pengembangan kurikulum anak usia dini. Landasan ini digunakan sebagai dasar untuk mengembangkan media Bola ENAK. Rancangan yang dipergunakan untuk mengembangkan media 'Bola ENAK' telah sesuai dengan tahapan tumbuh kembang anak karena semua ciri/karakteristik Multiple Intelligence yangmultisensori berbasis ramah lingkungan dapat dimunculkan. Penerapan dan aspek Multiple Intelligence diwujudkan ke dalam media'Bola ENAK'. Pengembangan media 'Bola ENAK' ini tidak hanya menghasilkan produk media bermain dan pembelajaran ,tetapi telah dihasilkan pula rumusan Standar Operasional Prosedure(SOP) yang di dalamnya memuat prosedur dan langkah langkah penggunaan media Bola ENAK sesuai jenis dan bentuknya.

DAFTAR PUSTAKA

Lippincott. 2013. Child and Adolescent Psychiatry. Journal of Play Therapy Vol 8 (2)(85- 108). Philadelphia. 
Madyawati, Lilis. .2017. Pengembangan Model Kurikulum Inclusi dalam Implementasi Sekolah Ramah Anak di Daerah Rawan Bencana Jawa Tengah. Laporan Penelitian (Hibah Muhammadiyah).

Madyawati, Lilis. 2015. Pengembangan Model Kegiatan Bermain Berbasis Kecerdasan Jamak dalam Implementasi Sekolah Ramah Anak di Daerah Rawan Bencana Jawa Tengah. Laporan Penelitian (Hibah DIKTI).

Madyawati, Lilis. 2016. Pengembangan Model Media Play TherapyBerbasis Kecerdasan Jamakdalam Implementasi Sekolah Ramah Anak di Daerah Rawan Bencana Jawa Tengah. Laporan Penelitian (Hibah DIKTI).

Spiegel, D. Multiple Personality as a posttraumatic stress disorder. Psychiatr Clin North Am 2004, 7: 101- 110.

Terr, L. 2007. Childhood Trauma and the Creativeproduct. Psychoanal study child; 42: 545- 572.

Von Hofsten, C. 2000. Predictive reaching for moving objects by human infants. Journal of Experimental Child Psychology, 30, 369- 382.

Wall, A.K., Reid, G., \& Paton, J. 2005. The Syndrome of Physical awkwardness. InG. Reid (Ed.). Problems in movement control (pp. 283-316). Amsterdam: North- Holland. 